\title{
WEATHER VARIABLES, WATER BALANCE, GROWTH, AND AGRO INDUSTRIAL YIELD OF SUGAR CANE
}

Doi:http://dx.doi.org/10.1590/1809-4430-Eng.Agric.v35n 1p 76-88/2015

\section{IÊDO TEODORO ${ }^{1}$, JOSÉ DANTAS NETO ${ }^{2}$, LUCAS A. DE HOLANDA ${ }^{3}$, GIVALDO D. SAMPAIO NETO ${ }^{4}$, JOSÉ L. DE SOUZA ${ }^{5}$, GERALDO V. DE S. B ARBOSA ${ }^{6}$, GUILHERME B. LYRA ${ }^{7}$}

\begin{abstract}
The objective of this study was to evaluate the meteorological variables, water deficiency, growth, and agro-industrial yield of sugarcane varieties: RB72454, RB863129, RB867515, RB92579, RB93509, RB931003, RB951541, and RB971755, in rainfed crop in two harvests in the Rio Largo-AL region. The meteorological variables were obtained in an automatic station and water balance was done by Thornthwaite \& Mather method. During the study period, the air temperature ranged from 16.6 to $35.9{ }^{\circ} \mathrm{C}$. In the first production cycle rained $1,806 \mathrm{~mm}$ and the crop evapotranspiration was $1,775 \mathrm{~mm}$. In the second cycle, the rainfall totaled 1,632 $\mathrm{mm}$ and the crop evapotranspiration was $1,290 \mathrm{~mm}$. The average water excess of two production cycles was $689 \mathrm{~mm}$ and the water deficit totaled $665 \mathrm{~mm}$. The average agricultural productivity in the plant was $86.8 \mathrm{t} \mathrm{ha}^{-1}$, in the first ratoon was $75.2 \mathrm{t} \mathrm{ha}^{-1}$ and the agro-ind ustrial yield average was 12.9 and 10.9 tons of sugar per hectare in the plant and first ratoon, respectively. The air temperature was not limiting to the growth of sugarcane and the rainfall was higher than the crop evapotranspiration, but due to poor distribution of the rains there was water deficit. The most productive varieties were RB93509, RB92579, and RB863129.
\end{abstract}

KEYWORDS : air temperature, rain, evapotranspiration, canopy height

\section{VARIÁ VEIS METEOROLÓGICAS, B ALANÇO HÍDRICO, CRESCIMENTO E PRODUTIVIDADE AGROINDUSTRIAL DA CANA-DE-AÇÚCAR}

\begin{abstract}
RESUMO. O objetivo deste trabalho foi avaliar as variáveis meteorológicas, a deficiência hídrica, o crescimento e a produtividade agroindustrial das variedades de cana-de-açúcar: RB72454, RB863129, RB867515, RB92579, RB93509, RB931003, RB951541 e RB971755, em cultivo de sequeiro, em duas safras, na região de Rio Largo - AL. As variáveis meteorológicas foram obtidas em uma estação automática, e o balanço hídrico foi feito pelo método de Thornthwaite \& Mather. No período da pesquisa, a temperatura do ar variou de 16,6 a $35,9^{\circ}$ C. No primeiro ciclo de produção, choveu $1.806 \mathrm{~mm}$, e a cultura evapotranspirou $1.775 \mathrm{~mm}$, e, no segundo ciclo, a precipitação pluvial somou $1.632 \mathrm{~mm}$, e a evapotranspiração da cultura foi $1.290 \mathrm{~mm}$. O excesso hídrico médio dos dois ciclos de produção foi $689 \mathrm{~mm}$; e o déficit hídrico, $665 \mathrm{~mm}$. Ou seja, mesmo resultando em uma precipitação pluvial superior à evapotranspiração da cultura, devido à má distribuição das chuvas, houve deficiência hídrica. A temperatura do ar não foi limitante para o crescimento da cana-de-açúcar. A produtividade agrícola média da cana-planta foi $86,8 \mathrm{t} \mathrm{ha}^{-1}$, em cana-soca foi 75,2 $\mathrm{t} \mathrm{ha}^{-1}$, e o rendimento agroindustrial médio foi 12,9 e 10,9 toneladas de açúcar por hectare em cana-planta e cana-soca, respectivamente. As variedades mais produtivas foram a RB93509, a RB92579 e a RB863129.
\end{abstract}

PALAVRAS-CHAVE: temperatura do ar, chuva, evapotranspiração, dossel vegetativo.

\footnotetext{
${ }^{1}$ Prof. Dr. da Universidade Federal de Alagoas - UFAL. (82) 9922 8744, iedoteodoro@ig.com.br.

${ }^{2}$ Prof. Dr. da Universidade Federal de Campina Grande - UFCG - PB, zedantas @ edag.ufcg.edu.br.

${ }^{3}$ Doutorando da UNESPE, BOTUCATU - SP, lucas_holanda_@ hotmail.com.

${ }^{4}$ Doutorando da UNESP, BOTUCATU - SP, givaldosampaio@bol.com.br.

${ }^{5}$ Prof. Dr. da Universidade Federal de Alagoas - UFAL, leonaldojs@y ahoo.com.br.

${ }^{6}$ Prof. Dr. da Universidade Federal de Alagoas - UFAL, gvsbarbosa@ gmail.com.

${ }^{7}$ Prof. Dr. da Universidade Federal de Alagoas - UFAL, gbastoslyra@y ahoo.com.br. 


\section{INTRODUCTION}

The sugarcane is essentially a tropical plant that produces well in areas where the air temperature is between 18 and $38{ }^{\circ} \mathrm{C}$, relative humidity $40-80 \%$ and average rainfall of $1,200 \mathrm{~mm}$ to $2,500 \mathrm{~mm}$ well distributed during the year ( DOOREMBOS \& KASSAN, 1979; SINGH et al., 2007 and FARIAS et al., 2008). In Brazil there are 110 million hectares suitable for the expansion of agriculture on a sustainable basis. Of this total, approximately $70 \%$ of the land is located in the "cerrado" biome (CHRISTOFIDIS, 2006) and in this region water deficit occurs annually between the months of May to October (SOUSA et. al., 2010).

The variability of meteorological elements, especially the pluvial precipitation, influences significantly the incomes of plantations, mainly in non-irrigated crops. The East coast of the Brazilian Northeast is a region of tradition in the cultivation of sugarcane. However, in 2010/2011 crop agricultural productivity in this area was 57.16 while in the Southeastern region reached 82.03 $\mathrm{t} \mathrm{ha}^{-1}$ (CONAB, 2011). The main cause of low agricultural productivity of Northeastern sugarcane is the uneven distribution of rainfall. Therefore, the knowledge of the regional climatic features is essential to identify the times of the year that are most likely to occur water deficiency and plan the activities of cultivation so that the phases of crop development more sensitive to drought (water stress) coincide with the greater availability of water in the soil (ALMEIDA et al., 2008).

The water stress is more damaging to the culture of sugarcane when it happens in phases of emergence and early vegetative growth. MACHADO et al. (2009) observed that the reductions in the number of internodes stem, dry matter and soluble solids (BRIX) are bigger when the water deficiency occurs between 100 and 120 days after planting. TEJERA et al. (2007) have observed that even until 140 days after planting (DAP) the growth rate of sugarcane is low, increasing from 141 to 300 DAP and then back down.

The sequential water balance proposed by THORNTHWAITE \& MATHER (1955) provides the basic information to be used in the management of agricultural crops, especially in the definition of the best planting and harvesting seasons. The water balance can also be used to explain the increases and reductions of productivity of agricultural enterprises or in extreme cases justify frustrations of vintages (LYRA et al., 2010 and TEODORO et al., 2009).

Resistance to water stress has been one of the main factors among many other features of the new varieties released by genetic improvement programs of sugarcane. Among other parameters, the height and the diameter of the plant stem have influence directly proportional with the agricultural productivity. In this way, varieties in which these parameters are little affected by water deficiency became an ind icative that they are tolerant to drought (SILVA et. al., 2008).

The use of new varieties more adapted to environment production, over the past three decades, has generated gains of up to $30 \%$ on sugarcane businesses income (BARBOSA et. al., 2000). The varietal census of 2008 showed that the varieties RB (Inter-University Network for the development of the Sugar-Ethanol sector - RIDESA) take up about 58\% of the planted area with sugarcane in the West of the State of São Paulo (CHAPOLA et. al., 2009). In this State, varieties like RB72454 and RB867515 together are planted in more than 23\% of the sugarcane fields and need to be replaced because they are already in cultivation for more than 20 years. Therefore, the selection of sugarcane varieties that can be more productive under water deficiency conditions is important to improve the yields of agro-ind ustrial sugarcane, especially in non-irrigated crops.

The aim of this study was to evaluate meteorological variables, hydro deficiency, growth and agro-industrial productivity on eight varieties of sugarcane in two production cycles in rainfed crop.

\section{MATERIAL AND METHODS}

The experiment was conducted at the Center of Agricultural Sciences at the Federal University of Alagoas in Rio Largo-AL (09 $28^{\prime}$ 02" S; 35 49'43'W; $127 \mathrm{~m}$ ), in a cohesive argisolic yellow latosol of silt medium-textured. Planting was done in September $16^{\text {th }}, 2005$; the first harvest took place in November $13^{\text {th }}, 2006$ and the second crop in November $23^{\text {rd }}, 2007$. The 
statistical design used was randomized blocks with four repetitions and eight treatments: the varieties RB72454, RB863129, RB867515, RB92579, RB93509, RB931003, RB951541 and RB971755 were planted in plots of 11 lines with 21 meters long. The spacing used was $1.0 \mathrm{~m}$ between lines, putting up 18 gems per linear meter.

The sugarcane plant fertilizing and liming were made based on the chemical analysis of the soil (table 1). Dolomite limestone was applied thirty days prior to planting (1,200 kg per hectare) and the foundation fertilization was performed by placing the fertilizer in the bottom of the furrow (1000 kg ha ${ }^{-1}$ of 10-20-20 formula corresponding to the level of $100 \mathrm{~kg} \mathrm{ha}^{-1}$ of N, $200 \mathrm{Kg} \mathrm{ha}^{-1}$ of $\mathrm{P}_{2} \mathrm{O}_{5}$ and $200 \mathrm{~kg} \mathrm{ha}^{-1}$ of $\mathrm{K}_{2} \mathrm{O}$ ). Sixty days after planting were placed in coverage 40, 20 and $30 \mathrm{Kg}$ $\mathrm{ha}^{-1}$ of copper sulphate, manganese and zinc, respectively, mixed with $90 \mathrm{Kg}$ of filter draff of cane to facilitate the distribution. The fertilization of the ratoon was held with $90 \mathrm{Kg} \mathrm{ha}^{-1}$ of N, $90 \mathrm{~kg} \mathrm{ha}^{-1}$ of $\mathrm{P}_{2} \mathrm{O}_{5}$ and $140 \mathrm{~kg} \mathrm{ha}^{-1}$ of $\mathrm{K}_{2} \mathrm{O}, 30$ days after cutting.

The meteorological variables (rainfall, relative humidity, wind speed, air temperature, net radiation and heat flux in the soil) were obtained in an automatic station for Micrologger mCR10X date acquisition (Campbell Scientific, Logan, Utah) installed 300 meters from the experiment.

TABLE 1. Results of the soil chemical analysis of the experimental area, in the layers: 0.0 to 0.20 $\mathrm{m}$ and 0.20 to $0.40 \mathrm{~m}$.

\begin{tabular}{llllll}
\hline Determinations & \multicolumn{2}{c}{ Results } & Determinations & \multicolumn{2}{c}{ Results } \\
& $0-20 \mathrm{~cm}$ & $20-40 \mathrm{~cm}$ & & $0-20 \mathrm{~cm}$ & $20-40 \mathrm{~cm}$ \\
\hline \hline PH in water & 6.5 & 6.1 & $\mathrm{~T}\left(\mathrm{mmol}_{\mathrm{c}} \mathrm{dm}^{-3}\right)$ & 86.5 & 73 \\
Phosphorus $\left((\mathrm{mg} \mathrm{dm})^{-3}\right)$ & 16 & 15 & $\mathrm{~V}(\%)$ & 49.1 & 37 \\
Potassium $\left(\mathrm{mg} \mathrm{dm}^{-3}\right)$ & 96 & 39 & $\mathrm{~m}(\%)$ & 0.7 & 8.5 \\
$\mathrm{Ca}+\mathrm{Mg}\left(\mathrm{mmol}_{\mathrm{c}} \mathrm{dm}^{-3}\right)$ & 40 & 26 & M. O. $\left(\mathrm{g} \mathrm{kg}^{-1}\right)$ & 17.7 & 11.2 \\
$\mathrm{Ca}\left(\mathrm{mmol}_{\mathrm{c}} \mathrm{dm}^{-3}\right)$ & 26 & 180 & Iron $\left(\mathrm{mg} \mathrm{dm}^{-3}\right)$ & 279.9 & 197.8 \\
$\mathrm{Mg}\left(\mathrm{mmol}_{\mathrm{c}} \mathrm{dm}^{-3}\right)$ & 14 & 8 & Copper $\left(\mathrm{mg} \mathrm{dm}^{-3}\right)$ & 1.19 & 0.93 \\
$\mathrm{Al}\left(\mathrm{mmol}_{\mathrm{c}} \mathrm{dm}^{-3}\right)$ & 0,3 & 2,5 & Zinc $\left(\mathrm{mg} \mathrm{dm}^{-3}\right)$ & 1.2 & 3.79 \\
$\mathrm{H}+\mathrm{Al}_{\left(\mathrm{mmol}_{\mathrm{c}} \mathrm{dm}^{-3}\right)}$ & 44 & 46 & Manganese $\left(\mathrm{mg} \mathrm{dm}^{-3}\right)$ & 4.38 & 16.86 \\
$\mathrm{~S}(\mathrm{sum} \mathrm{of} \mathrm{bases})$ & 42,5 & 27 & & & \\
\hline
\end{tabular}

The crop evapotranspiration (ETc) was calculated by multiplying the reference evapotranspiration (ETo) for crop coefficient (kc) of FAO, whose initial phase value (0.40) was corrected by the graphical method presented by ALLEN et al. (1998), as a function of time interval between the events of rainfall and the magnitude of the Eto. The Kc values of intermediate and final phases were corrected by [eq. (1)].

$$
K_{C}=K c_{\text {Tabled }}+\left[0.04\left(U_{2}-2\right)-0.004\left(U R_{\text {min. }}-45\right)\right]\left[\frac{h}{3}\right]^{0.3}
$$

where,

$\mathrm{Kc}$ is the crop coefficient;

$\mathrm{Kc}_{\text {tabled }}$ is the Kc of FAO tabled for sugarcane;

$\mathrm{U}_{2}$ is the velocity of the wind at $2.0 \mathrm{~m}$ above of the grass; 
$\mathrm{UR}_{\min }$ is the minimum air relative humidity, and

$h$ is the height of the vegetative canopy of culture.

After the correction, the Kc values used were: initial phase (0.90), intermediate phase (1.30) and finals (0.70) and the reference evapotranspiration was estimated by the method of PenmanMonteith (FAO) according to [eq. (2)].

$$
\cdot E T_{o}\left(m m . d a y^{-1}\right)=\frac{0.408 \Delta\left(R_{n}-G\right)+\left(\gamma \frac{900}{T+273}\right) U_{2}\left(e_{s}-e\right)}{\Delta+\left[\gamma\left(1+0.34 U_{2}\right]\right.}
$$

where,

$\Delta$ is the curve slope of saturated vapor pressure versus temperature $\left(\mathrm{kPa}^{\circ} \mathrm{C}^{-1}\right)$;

$\mathrm{Rn}$ is the balance of radiation $\left(\mathrm{MJ} \mathrm{m}^{-2} \mathrm{day}^{-1}\right)$;

$\mathrm{G}$ is the heat flux in the soil $\left(\mathrm{MJ} \mathrm{m}^{-2} \mathrm{day}^{-1}\right)$;

$\gamma$ is the psychometric coefficient $\left(\mathrm{kpa}^{\circ} \mathrm{C}^{-1}\right)$;

$\mathrm{T}$ is the average temperature of the air;

$\mathrm{U}_{2}$ is the velocity of the wind at $2 \mathrm{~m}$ height $\left(\mathrm{m} \mathrm{s}^{-1}\right)$;

" $e_{\mathrm{s}}$ " is the saturation pressure of water vapor in the air $(\mathrm{kPa})$, and

$" e$ " is the pressure of the air water vapor $(\mathrm{kPa})$.

The water balance method was according to THORNTHWAITE \& MATHER (1955), considering $60.0 \mathrm{~mm}$ of soil water storage capacity on $0.60 \mathrm{~m}$ depth.

The growth of the culture was evaluated based on the height of the canopy, whose measurements were performed monthly. Agricultural productivity was estimated by weighing the production of three central rows of each plot (63 linear $\mathrm{m}$ ), with a dynamometer bound to a sugarcane loader.

Agro-industrial income were determined by the quantity of sugar produced, expressed in tons of sugar per hectare (TSH). This index was calculated by multiplying agricultural productivity by the amount of total recoverable sugars (TRS), although STUPIELLO (2009) recommend the use of RTS (Reducing Total Sugars) to assess the quality of the raw material. In this study was used the TRS values calculated by the formula adopted by the Council of Sugarcane, Sugar and Alcohol Producers in the State of Alagoas and Pernambuco (CONSECANA), according to [eq. (3)].

$$
R T S_{A L-P E}=9.36814 \times P C+8.9 \times R S S
$$

where,

PC-pol of cane $(\%)$,

RSS-recoverable sugars from sugarcane (percent).

Chemical analysis of the sugarcane to determine the PC and the RSS was made at the laboratory of Usina Santa Clotilde sugar mill, located in Rio Largo - AL with 15 stems of each plot. 


\section{RESULTS AND DISCUSSION}

Daytime air temperature for the period from September 2005 to February 2008, ranged virtually within the interval of 16.6 to $35.9^{\circ} \mathrm{C}$. The values below $18^{\circ} \mathrm{C}$ were observed only five times in a period of 880 days, and values above $35^{\circ} \mathrm{C}$ were recorded only in the second 10-day period of November 2006 and the second 10-day period of February 2007 (Figure 01). It is important to point out that the diurnal minimum temperature below $18^{\circ} \mathrm{C}$ occurred between 6 and 7 in the morning, at the time the metabolism of the plants are still slow and the photo assimilation consumption is low and the development of the plants were not affected by air temperature. During this same period the nighttime temperature ranged from 16.1 to $28.8^{\circ} \mathrm{C}$ with only 13 values below $18^{\circ} \mathrm{C}$. These results indicate that the air temperature in the studied region is located within the optimum range for the growth and development of sugarcane according to MARIN (2007) who recommended as ideal hot and humid climate with temperatures between 19 and $32^{\circ} \mathrm{C}$.

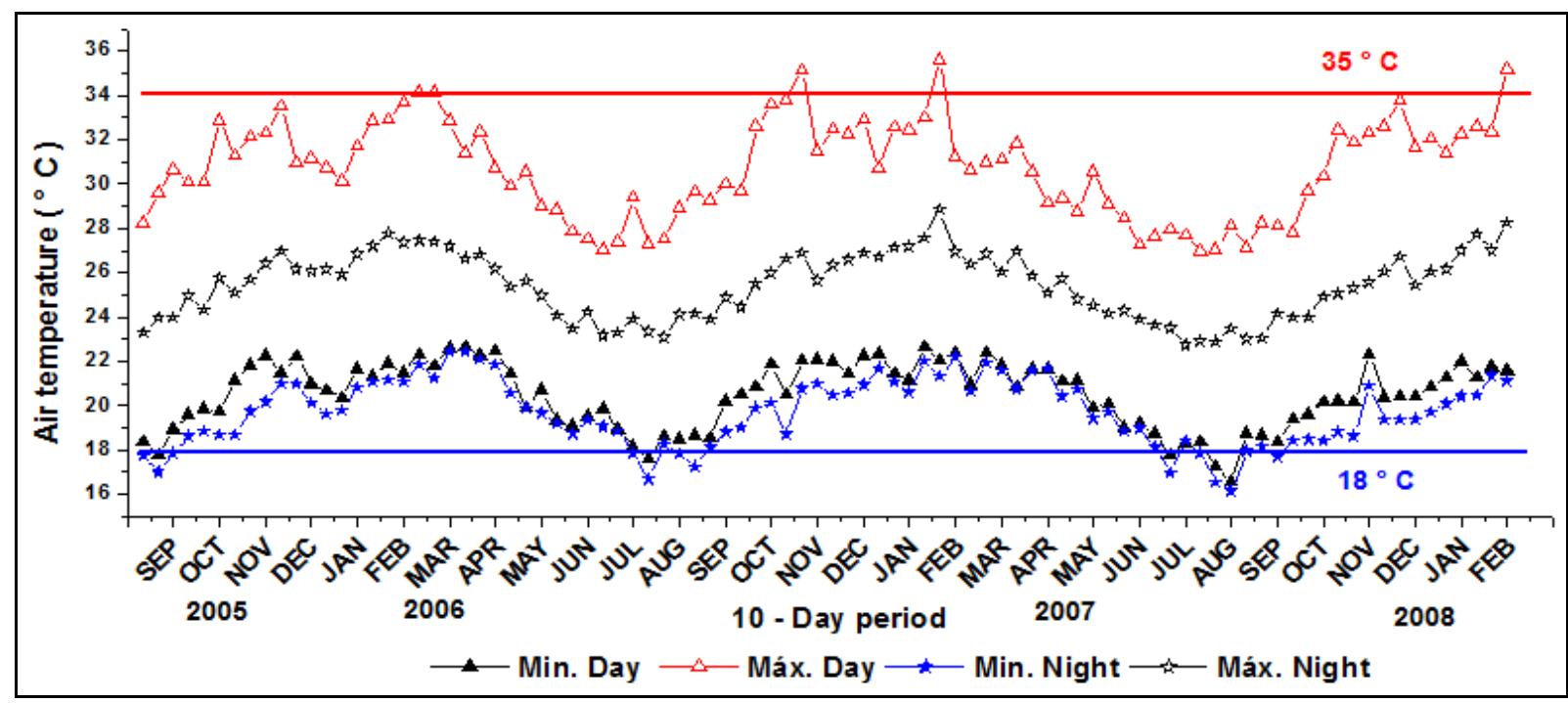

FIGURE 1. Air temperature, minimum daytime (Min. Day.), maximum daytime (Max. Day.), minimum night-time (Min. Night.) and maximum night-time (Max. Night.), in the period from September 2005 to February 2008, in Rio Largo - AL region.

Total pluvial precipitation in the first cultivation cycle ( from September 2005 to November 2006 - 424 days) was $1,806 \mathrm{~mm}$ and the evapotranspiration of the culture ranged from 1.58 to 5.9 $\mathrm{mm}_{\text {day }}{ }^{-1}$, average $4.18 \mathrm{~mm} \mathrm{day}^{-1}$, totaling 1,775 mm during the same period (Figure 02) .Despite of the total rain was over ETc, there was water deficiency in some ten day period because in the planting of September 16, 2005 until the $2^{\text {nd }}$ ten day period of March 2006 rained only $204 \mathrm{~mm}$ (average of $1.20 \mathrm{~mm} \mathrm{day}^{-1}$ ) while the ETc amounted to $715 \mathrm{~mm}$ (average of $4.06 \mathrm{~mm} \mathrm{day}^{-1}$ ). In the final phase of sugarcane cultivation (the $1^{\text {st }}$ ten day period in September to harvest on November 13, 2006 - 74 days) rained only $75 \mathrm{~mm}$ and evapotranspiration reached $369 \mathrm{~mm}$. On the other hand, this deficiency favored the maturation of sugarcane and contributed to the increase in sucrose content.

In 2006, the rainy season began in the second ten days of March and lasted until the first ten days of September, with average rainfall of $8.2 \mathrm{~mm} \mathrm{day}^{-1}$ for 184 days totaling $1,509 \mathrm{~mm}$ while the total ETc was only $718 \mathrm{~mm}\left(3.9 \mathrm{~mm} \mathrm{day}^{-1}\right)$, this confirms the existence of water surplus in the region at this time of the year. 


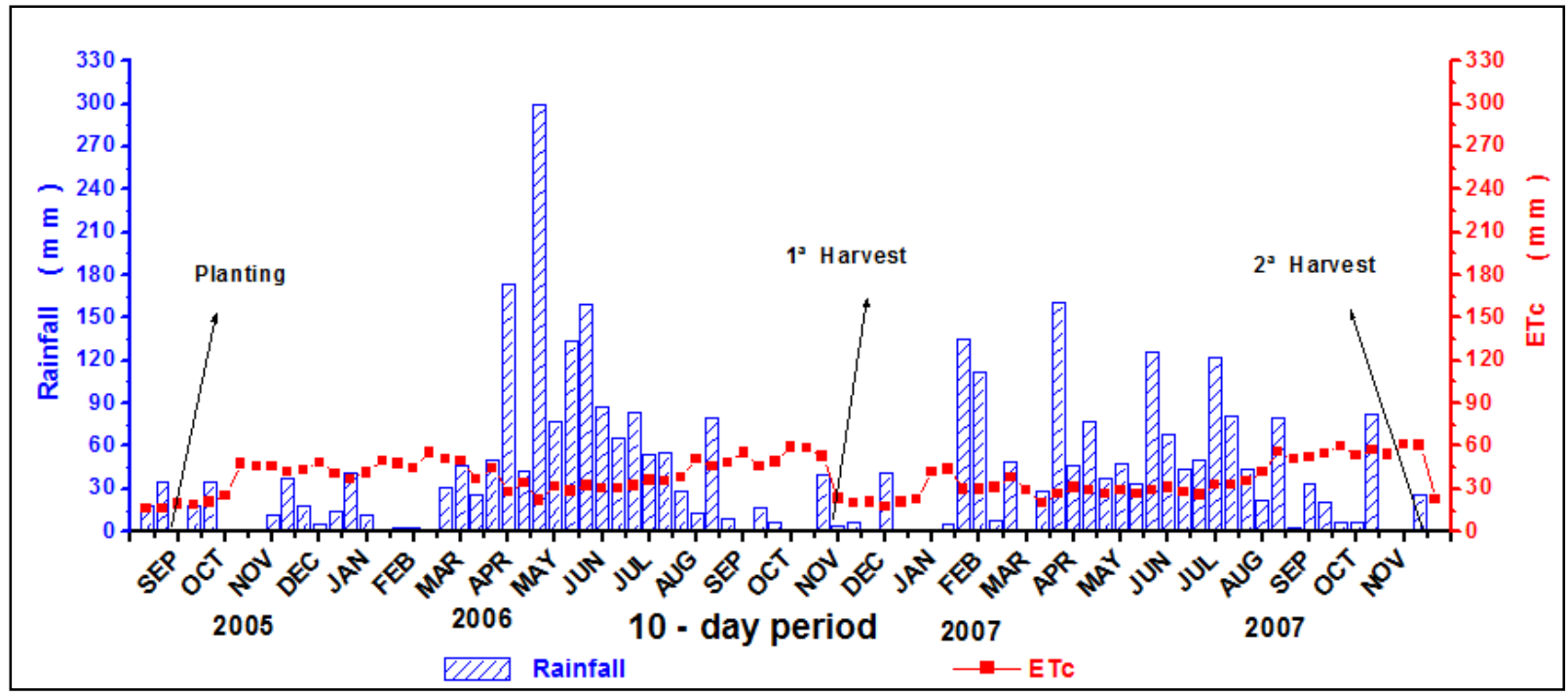

FIGURE 2. Rainfall and crop evapotranspiration of sugarcane (ETc) in two crop cycles, from September 2005 to November 2007, in the Rio Largo - AL region.

SINGH et al. (2007), in sandy loam soil, accounted the average water usage of 1,362 and 1,161 mm per year in sugarcane and ratoon, respectively. MOROIZUMI, et. al. (2009), working with sugar cane and rice in Northeast Thailand, noted that the average evapotranspiration in the areas of shimmery is $3.7 \mathrm{~mm} \mathrm{day}^{-1}$ and on the slopes or highlands is $4.2 \mathrm{~mm} \mathrm{day}^{-1}$. INMANBAMBER \& SMITH (2005), using the Bowen method of energy ratio balance (BERB), found ETc maximum $8.0 \mathrm{~mm} \mathrm{day}^{-1}$ in Australia and $7.0 \mathrm{~mm} \mathrm{day}^{-1}$ in Swaziland but also report maximum lysimetric measures in Australia of $6.8 \mathrm{~mm} \mathrm{day}^{-1}$.LYRA et al. (2,007) researching ETc on sugarcane, from August 2000 to November 2001, in the climatic region of Maceio-AL, found a total ETc of $2050.0 \mathrm{~mm}$ in 450 days, mean of $4.6 \mathrm{~mm}^{\text {day }}{ }^{-1}$.

The pluvial precipitation in the year 2006 amounted $1,710 \mathrm{~mm}$ and $88.5 \%$ of this amount was recorded during the rainy season (from March to August) and the annual ETc was 1,448 mm. The crop evapotranspiration varies according to the sowing season, especially long production cycles of crops such as sugarcane. In the sugarcane region of the east coast of Northeast Brazil there are two planting seasons, from June to August (dry land planting) and from October to January of the following year (irrigated crop).

In the second cycle of cultivation which was the third 10-day period from November 2006 until the second 10-day period of November 2007, a 374 days period, it rained 1,632 mm and evapotranspirated $1,290 \mathrm{~mm}$, but in the same way that happened in the first cycle, also water deficits occurred in two seasons, at the beginning and at the end of cultivation, interspersed by a period of water surplus that was the first 10-day period of April to the third 10-day period of August 2007. On the first ratton cultivation period, rain distribution was better than in the plant cycle of the sugarcane so that at the beginning of the development of the plants, from November $23^{\text {rd }}, 2006$ to April $29^{\text {th }}, 2007$ rained $679 \mathrm{~mm}$ and evapotranspired $476 \mathrm{~mm}$. At that stage there was water deficit because $36.4 \%$ of the rain fell in the first and second 10-day period of February causing a surplus of water in the soil. During the rainy season in 2007 which began in April and extended until September $20^{\text {th }}$, rained $1,079 \mathrm{~mm}$, corresponding to $68.8 \%$ of the pluvial precipitation of the year which was $1,567 \mathrm{~mm}$. In the years 2006 and 2007, on average, $78.7 \%$ of the pluvial precipitation occurred during the rainy season and this features a poor distribution of rainfall.

In the Tabuleiros Costeiros region in the state of Alagoas, the average relative humidity is $82 \%$, the average minimum air temperature is $20.9^{\circ} \mathrm{C}$ and the average maximum is $29.8^{\circ} \mathrm{C}$. These climatic parameters are conducive to the cultivation of sugarcane. The average annual rain precipitation in this region is $1,800 \mathrm{~mm}$, and $70 \%$ of this total occurs in the period from April to August (rainy season) and, from October to February, there is a high likelihood of water deficiency (SOUZA et al., 2004). 
The water balance in ten-day period of the Figure 03 can be noted that from the planting $\left(2^{\text {nd }}\right.$ ten-day period in September 2005) until $2^{\text {nd }}$ ten-day period in April 2006 there were water deficiency of $528 \mathrm{~mm}$. During this period the sugarcane did not die because there was little rain events, mainly during the months of November and December 2005 as seen in Figure 02 .These events of rain were enough to reset the hydrous deficit on the two occasions, the first 10-day period in December 2005 and in the $2^{\text {nd }} 10$-day period in January 2006. In 2006 it was counted a water excess of $834 \mathrm{~mm}$ between the third 10-day period in April and the third 10-day period in August. Then there was another drought period of 60 days (from September $21^{\text {st }}$ till November $20^{\text {th }}$, soon after the sugarcane harvest) which accumulated a water deficit of $146 \mathrm{~mm}$. So, during the production cycle of 424 days of sugarcane occurred a total water deficit of $674 \mathrm{~mm}$. In the 10-day period before the first harvest, rained $41 \mathrm{~mm}$ which did not reset the hydric deficiency but favored the sprouting of ratoon (second cycle of cultivation). The total excess water during the second growing season was $544 \mathrm{~mm}$, divided into two periods: a) the second ten-days perid of March (112 $\mathrm{mm}$ ) and b) of the third ten day period of April to the third ten-days perid of August (432 mm). Total water deficiency, observed in three periods of the second production cycle, amounted to 657 $\mathrm{mm}$. This indicates that the distribution of rainfall in the growing cycle of the first ratoon was better than the cycle of the sugarcane because water deficiency was more extended, however less intense, that is, without reaching, high levels on time.

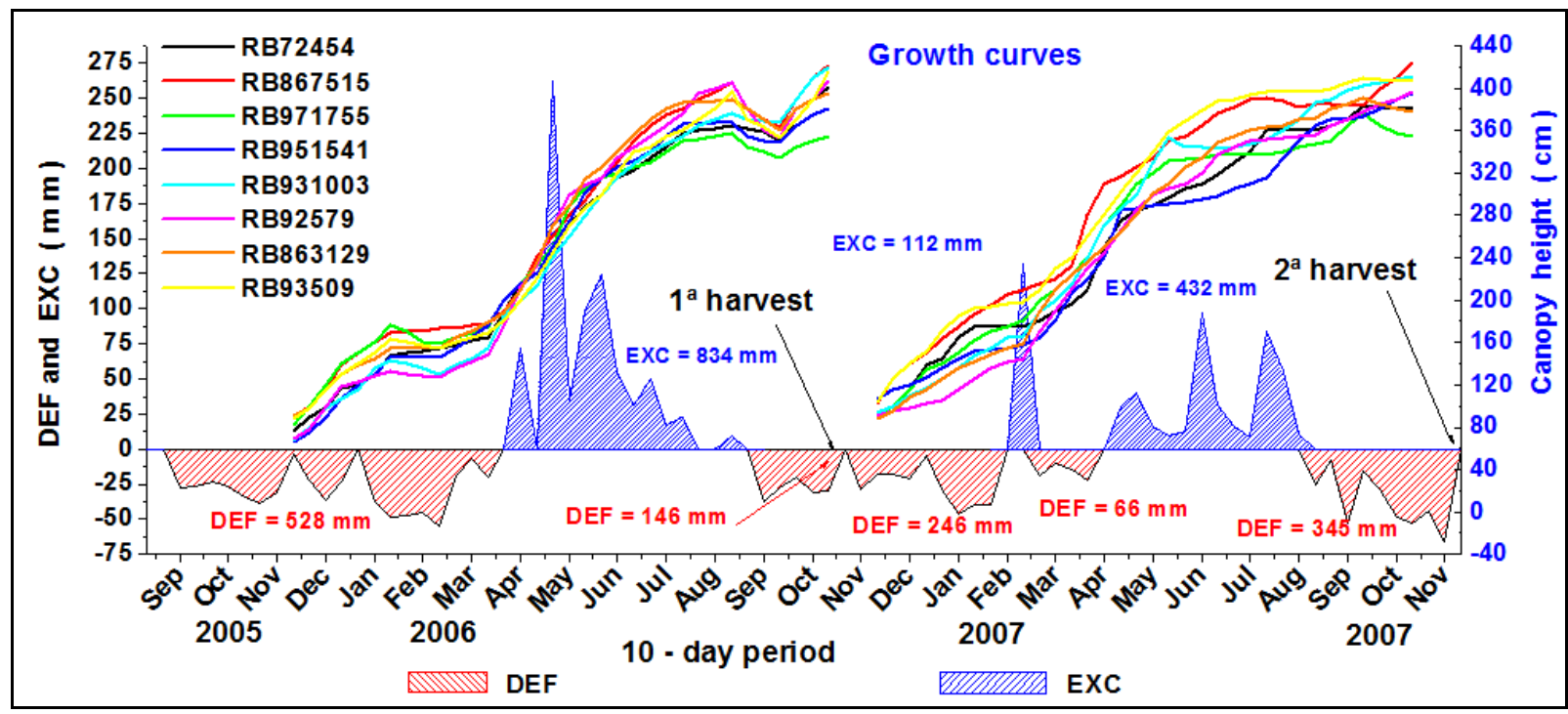

FIGURE 3. Water balance of sugarcane crop, with details of the water deficit (DEF), water excess (EXC) and growth curves of the canopy height of eight sugarcane varieties, in two crop cycles, from September 2005 to November 2007, in the Rio Largo - AL region.

The water balance of the culture in the two crop cycles analyzed presented on average 689 $\mathrm{mm}$ of hydric excess and $665 \mathrm{~mm}$ of water deficiency. So if there are physical structures such as dams, and lakes to store water surplus, will not lack water for irrigation during the dry season in the region studied in this research .During the studied period in that climate region, it was observed that from September to March there is high probability that occurs water deficiency. It is therefore not recommended to perform sugarcane plantations without the use of irrigation, at this time.

The growth curves of the crop represented by the height of the canopy were significantly affected by water deficiency. This can be observed at the beginning of the vegetative growth of the sugarcane (Figure 03). Since the first ten-day period of December 2005, when water deficiency decreased, until the third 10-day period of January 2006 the plants grew on average $1.03 \mathrm{~cm} \mathrm{day}^{-1}$. After this period the water deficiency in the soil increased and the plants height remained practically stable until the first 10-day period of April, when the culture grew back, coinciding with the beginning of the rainy season which is characterized by the water excess in the soil. In the ratoon crop cycle is also observed a small stabilization on plant growth always in tune with periods 
of water stress. WIEDENFELD \& ENCISO (2008), in a sugarcane plantation drip irrigated in South Texas-US A, was observed a grow th rate of 1.31 to $1.50 \mathrm{~cm} \mathrm{day}^{-1}$.

At the beginning of the growth of the sugarcane it has been observed that the RB867515 and RB971755 varieties have grown more than the others and in the period from April to June (average of $\left.1.69 \mathrm{~cm} \mathrm{day}^{-1}\right)$ which presented virtually the same rate of growth $\left(1.64 \mathrm{~cm} \mathrm{day}^{-1}\right)$. But after the first 10-day period from June, the RB92579 stood out from the rest and grew at a rate of $1.3 \mathrm{~cm} \mathrm{day}^{-}$ 1, so that in September it and RB867515 were both with a canopy $405 \mathrm{~cm}$ tall, been the highest.The height of the vegetative canopy is a parameter of sugarcane that draws attention of producers and researchers by visual impression and the correlation with the agricultural productivity. At the end of the production cycle of the sugarcane, the highest varieties were: RB867515, RB931003, RB93509 and RB92579 that reached a height of canopy of 421, 419, 415, and $407 \mathrm{~cm}$, respectively.

In the growth cycle of the second leaf (first ratoon) the varieties showed the same growth profile with RB867515 and RB72454 growing faster than the other and the RB92579 being the least to the first ten-day period of November 2007 when it reached $397 \mathrm{~cm}$ tall and was second only to RB867515 which reached $424 \mathrm{~cm}$. In this crop, water deficiency began early (in the first 10-day period of September) and undermined the growth of varieties, especially the growth of RB92579 which is characterized for keeping the growth rate in the final phase of growing above the other cultivars used in this experiment. WIEDENFELD \& ENCISO (2008) evaluating the growth of sugarcane in four cycles of cultivation (sugarcane until the third ratoon, irrigated by drip) observed an average height of stem of $208 \mathrm{~cm}$, with an average growth rate of $1.50 \mathrm{~cm} \mathrm{day}^{-1}$. SILVA et al. (2009) studying the variety SP-791011 in the State of Paraiba (Brazilian northeast) observed that in 12 months of cultivation of second ratoon, produced stem with $231 \mathrm{~cm}$ in length, in irrigated planting and $185 \mathrm{~cm}$ in non-irrigated dry land crop.

In the Figure 04 is the agro industrial yield of sugarcane plant, expressed in tons of sugar per hectare (TSH). In this figure are presented the isoquant or isoproduct lines so that varieties with agricultural productivity (ton of sugarcane per hectare- $\mathrm{TScH}$ ) lower than others may stay at the same isoquant since cultivars with lower $\mathrm{TScH}$ have greater amounts of total recoverable sugar (displayed on the axis of abscissas-TRS). This happened with the varieties RB93509 and RB863129 who had 98.5 and 97.4 of TSCH, respectively, but as the RB863129 had the TRS superior than RB93509, both of these can be found on the isoquant of 14.0 tons of sugar per hectare.

In isoquants-type figures, the variety that is closer to the upper-right corner is the one with the largest agro-ind ustrial income. Thus, RB92579, RB93509, and RB863129 varieties were the most productive with TScH of 101,40; 98.50 and 97.40; TRS of 157.0; 142.0 and 143.5 and TSH of 15.9; 14.1 and 13.9, respectively. CALHEIROS et al. (2011) planted the RB867515 and RB92579 varieties in the region of Rio Largo-AL (Brazilian northeast) and managed to produce 126 and 129 tons of sugarcane per hectare, in the same order.

The average agricultural productivity of sugarcane (presented on Figure 4 and expressed in $\mathrm{TScH}$ ) was $86.85 \mathrm{t} \mathrm{ha}^{-1}$ and the TRS was on average 148.56 kilograms per ton of sugarcane. This generated an average TSH of 12.9. The variety RB867515 produced a TSH of 12.9 and stayed at the same isoquant of agribusiness middle income. The agro-industrial yield isoquants of ratoon (Figure 05) indicate that the RB93509 in this crop cycle was the most productive, with agricultural productivity of $95.8 \mathrm{t} \mathrm{ha}^{-1}$ and $146.9 \mathrm{~kg}$ of TRS per ton of stem giving an agricultural yield of 14.0 tons of sugar per hectare. The RB931003 and RB92579 were in the same isoquant average $(\mathrm{TSH}=$ 10.9), with yields of 11.8 and 11.4 of TSH, respectively.

In the second cultivation cycle, the less productive variety was RB971755 with TSH of just 8.9. The final yield of this variety was low because the agricultural productivity of 60 tons ha ${ }^{-1}$ was below average that was 75.2 tons $\mathrm{ha}^{-1}$. In a general analysis of this research, it is necessary to take into account that all varieties were harvested in the same season (beginning of harvest) and that certainly hurt the final yield of late varieties because they were taken when they were still increasing sucrose content. 
The agro-industrial yield of RB92579 variety in ratoon was inferior to the RB93509 and RB931003 varieties because one of RB92579 features is the high growth rate at the end of the production cycle and in 2007 the dry season along with the period of water deficiency began earlier (first ten days of September) and that damaged the end of crop growth so that agricultural productivity of the same was only 76.2 tons $\mathrm{ha}^{-1}$. The average yield of the first ratoon was: $\mathrm{TScH}=$ 75.2; $\mathrm{TRS}=144.8$ and $\mathrm{TSH}=10.89$.

At the Pirassununga region-SP (Brazil), FRANCO et al. (2009) reported that when using the doses of 0.0 and $3.0 \mathrm{~kg}$ of zinc per hectare produced 141 and 138 tons of sugarcane per hectare $(\mathrm{TScH})$ and 18.89 and 20.28 tons of sugar per hectare, respectively. MARQUES et al. (2007) in the West of São Paulo (Brazil) cultivated varieties RB867515 and RB72454, considered late (sugarcane to be harvested in late vintages), and obtained $\mathrm{TScH}$ of 79.1 and 74.8, respectively.

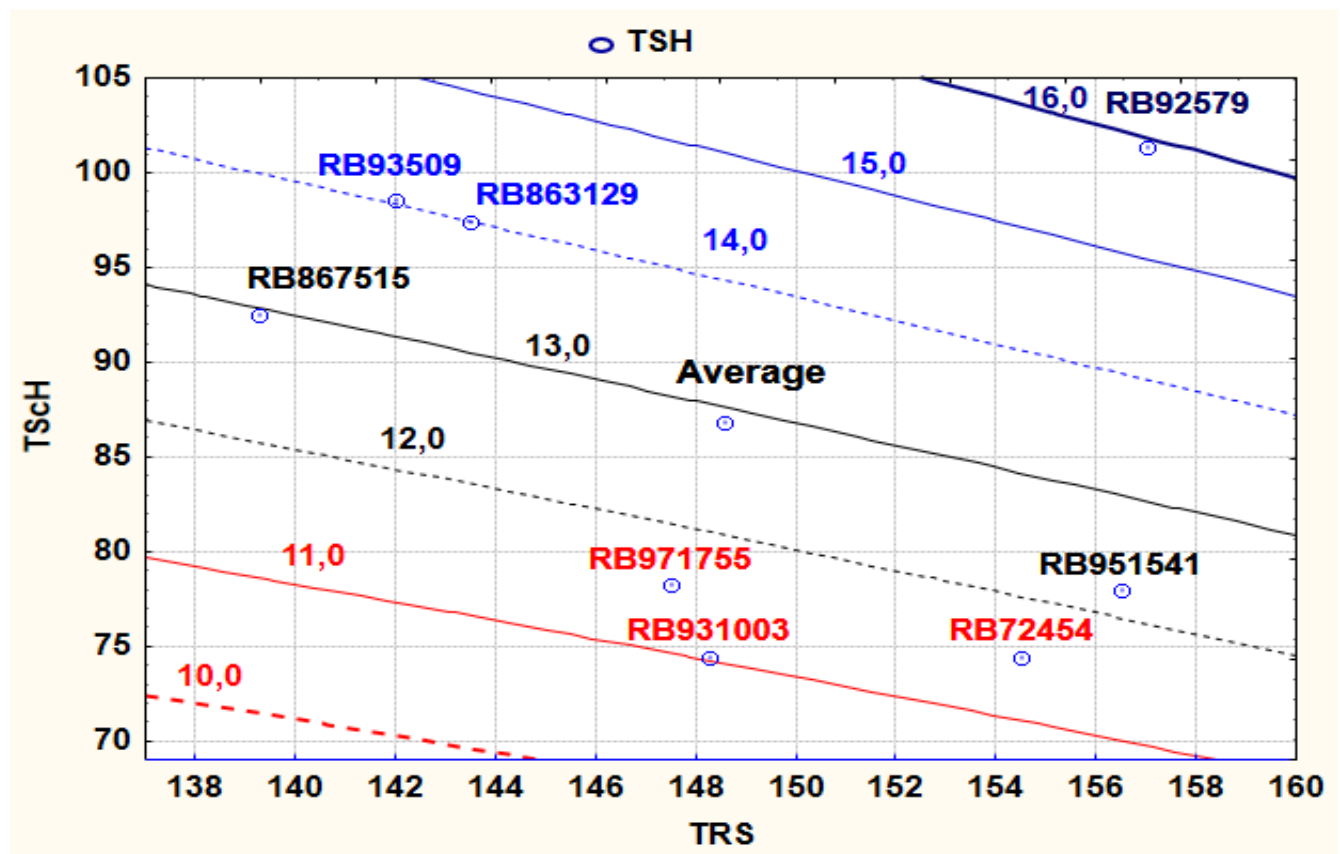

FIGURE 4. Isoproduct or isoquant curves of the agro-ind ustrial yield in tones of sugar per hectare $(\mathrm{TSH})$, in function of the agricultural productivity in tones of sugarcane per hectare $(\mathrm{TScH})$, and kilograms of commercially recoverable sucrose content per ton of sugarcane (TRS) of eight sugarcane varieties, in rainfed crop, plant crop, in the Rio Largo - AL region, in the 2006/2007 harvest.

In Figure 06 notes the total income of two agribusiness crops analyzed. The most productive varieties were RB93509, RB92579, and RB863129 who obtained yields of 28.1, 27.3, and 24.1 tons of sugar per hectare, respectively. While the RB971755 and RB72454 varieties were the least profitable, with TSH of 20.4 and 21.8, in the same order. 


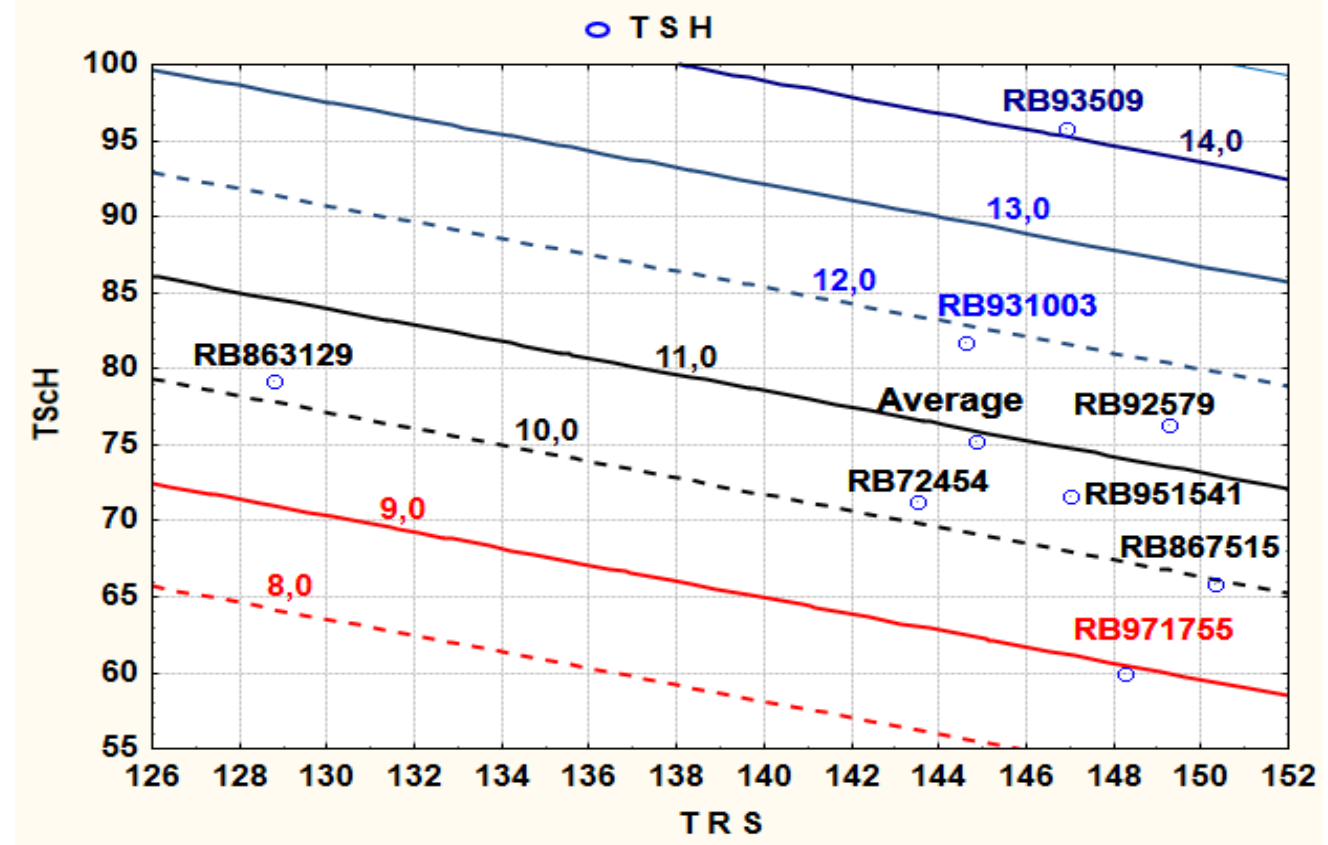

FIGURE 5. Isoquants of the agro-industrial yield in tones of sugar per hectare (TSH), in function of the agricultural productivity in tones of sugarcane per hectare $(\mathrm{TScH})$, and kilograms of commercially recoverable sucrose content per ton of cane (TRS) of eight sugarcane varieties, in rainfed crop, first ratoon, in the Rio Largo - AL region, in the 2007/2008 harvest.

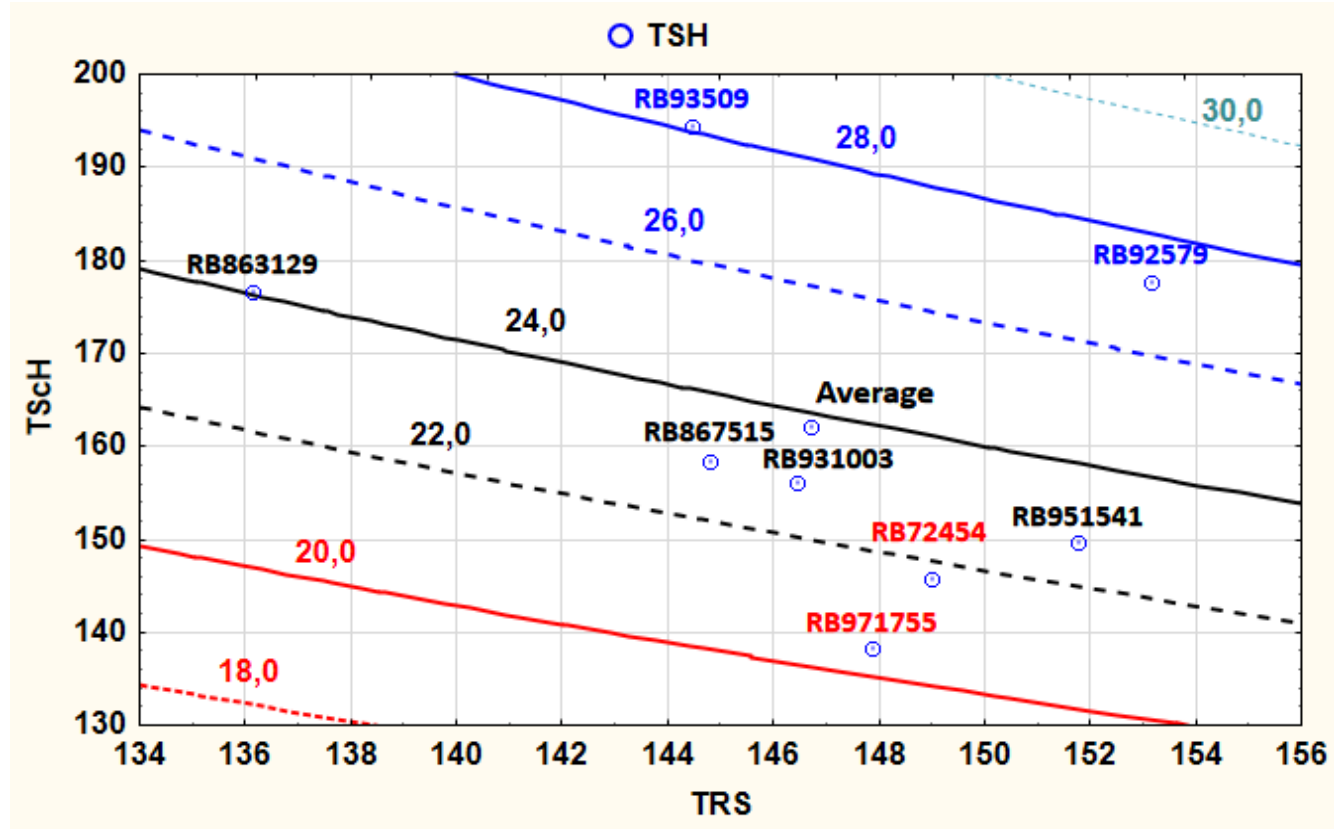

FIGURE 6. Isoquants of the agro-ind ustrial yield in tones of sugar per hectare (TSH), in function of the agricultural productivity in tones of cane per hectare (TSCH), and kilograms of commercially recoverable sucrose content per ton of cane (TRS) of eight sugarcane varieties, in rainfed crop, total of two crop cycles, in the Rio Largo - AL region, in the 2006/2007 and 2007/2008 harvest. 


\section{CONCLUSIONS}

1. During the period of this field experiment, the air temperature was not limiting for sugarcane growth.

2. Despite of the pluvial precipitation is higher than the crop evapotranspiration there was water shortage due to poor distribution of rainfall.

3. The water deficit observed, from September to March, coincides with the planting season, harming the initial development of the sugarcane plant. The probability of this deficiency occurs in the region of Tabuleiros Costeiros from Alagoas, in the cited period is high, so it is not recommended the planting of sugarcane without irrigation during this period.

4. The most productive varieties were the RB93509, the RB92579 and the RB863129 and the less productive were the RB971755 and the RB72454.

\section{ACKNOWLEDGMENTS}

The authors thank the program of genetic improvement of sugarcane (PMGCA - UFAL), the Research Foundation of the State of Alagoas (FAPEAL) and the Council for scientific and techno logical de velopment (CNPq).

\section{REFERENCES}

ALLEN, R. G.; PEREIRA, L. S.; RAES, D.; SMITH, M. Crop evapotranspiration: Guidelines for computing crop water requirements.(FAO: Rome, 1998. 300p. Irrigation and Drainage Paper 56).

ALMEIDA, A. C. dos S.; SOUZA, J. L.; TEODORO, I.; BARBOSA, G. V. de S.; MOURA FILHO, G.; FERREIRA JUNIOR, R. A. Desenvolvimento vegetativo e produção de variedades de cana-de-açúcar em relação a disponibilidade hídrica e unidades térmicas. Ciência e Agrotecnologia, Lavras, v. 32, n. 5, p. $141-148$, set. / out., 2008.

BARBOSA, G.V.S.; SOUZA, A.J.R.; ROCHA, A.M.C.; RIBEIRO, C.A.G.; FERREIRA, J.L.C.; SOARES, L.; CRUZ, M.M.; SILVA, W.C.M. Novas variedades RB de cana-de-açúcar para Alagoas. Maceió: UFAL; 2000. 16p. (Boletim Técnico do Programa de Melhoramento Genético de Cana-de-açúcar).

CAlHEIROS, A. S.; OlIVEIRA, M. W. de.; FERREIRA, V. M.; BARBOSA, G. V. de S.; COSTA, J. P. V. da.; LIMA, G. S. de A.; ARISTIDES, E. V. dos S. Acúmulo de nutrientes e produção de sacarose de duas variedades de cana-de-açúcar na primeira rebrota, em função de doses de fósforo. STAB, Piracicaba, v. 29, n. 3, p. 34 - 37, jan. / fev. 2011.

CHAPOLA, R. G.; SANTOS, E. G. D. dos; ROSA, J. R. B. F.; FERNANDES JUNIOR, A. R.; BASSINELlO, A. I.; VIEIRA, M. A. S.; HOFFMANN, H. P. Censo varietal de cana-de-açúcar do estado de São Paulo em 2008. STAB, Piracicaba, v. 27, n. 5, p. 36 - 39, mai. / jun. 2009.

CHRISTOFIDIS, D. Água: gênese, gênero e sustentabilidade alimentar no Brasil. Brasília, DF: GWA, 2006. 18p.

CONAB - Companhia Nacional De Abastecimento. Safra 2010/2011. Terceiro Levantamento. Disponível em: <www.conab.gov.br〉. Acesso em: 30 mar. 2011.

DOOREMBOS, J.; KASSAN, A. H. Yield response to water. Roma: FAO, 1979. 193p.(Irrigation and Drainage, paper 33).

FARIAS, C. H. A.; FERNANDES, P. D.; DANTAS NETO, J.; GHEYI, H. R. Eficiência no uso da água na cana-de-açúcar sob diferentes lâminas de irrigação e níveis de zinco no litoral paraibano. Engenharia Agrícola. Jaboticabal, v. 28, n.3, p.494-506, jul./set. 2008

FRANCO, H. C. J.; TRIVELIN, P. C. O.; VITTI, A. C.; FARONI, C. E.; SARTORI, R. H. Produtividade e atributos tecnológicos da cana-planta relacionados à aplicação de zinco. STAB, Piracicaba, v. 27, n. 5, p. $30-34$, maio/ jun. 2009. 
INMAN-BAMBER, N. G.; SMITH, D. M. Water relations in sugarcane and response to water deficits. Field Crops Research, Amsterdam, n. 92, p. 185 - 202. 2005.

LYRA, G. B.; SEDIYAMA, G. C.; LYRA, G. B.; PEREIRA, A. R.; SOUZA, E. F. de. Evapotranspiração da cultura de cana-de-açúcar na região de tabuleiros costeiros do Estado de Alagoas: coeficiente de cultura "único" padrão boletim FAO - 56. STAB, Piracicaba, v. 25, n. 4, p. 40 - 43, mar./abr. 2007.

LYRA, G. B.; LYRA, G. B.; SOUZA, J. L.; SANTOS, M. A. Balanço seqüencial de água no solo para o manejo da irrigação de baixa frequiência e alta intensidade na cana-de-açúcar. STAB, Piracicaba, v. 28, n. 4, p. 30 - 33, mar./ abr. 2010.

MACHADO, R. S.; RIBEIRO, R. V.; MARCHIORI, P. E. R.; MACHADO, D. F. S. P.; MACHADO, E. C.; LLANDELL, M. G. de A. Respostas biométricas e fisiológicas ao déficit hídrico em cana-de-açúcar em diferentes fases fenológicas. Pesquisa Agropecuária Brasileira, Brasília, v. 44, n. 12, p. 1575 - 1582, dez. 2009.

MARIN, F. R. Cana-de-açúcar. "Pré-produção características". Brasília: Agência de Informação Embrapa, 2007. Disponível em: <www.agencia.cnptia.embrapa.br/gestor/cana-de-açúcar>. Acesso em: 31 jul. 2011.

MARQUES, T. A.; GODINHO,A. M. M.; TIRITAN, C. S.; CRESTE, J. E.; MARQUES, M. O. Parâmetros biométricos e tecnológicos de cultivares de cana-de-açúcar para o Oeste paulista. STAB, Piracicaba, v. 26, n. 2, p. 46 - 51, nov./ dez. 2007.

MOROIZUMI, T.; HAMADA, H.; SUKCHAN, S.; IKEMOTO, M. Soil water content and water balance in rainfed fields in northeast Thailand. Agricultural Water Management, Amsterdam, n. 96, p. 160 - 166. 2009.

SILVA, C. T. S. da; AZEVEDO, H. M. de; AZEVEDO, C. A. V. de; DANTAS NETO, J.; CARVALHO, C. M. de; GOMES FILHO, R. R. Crescimento da cana-de-açúcar com e sem irrigação complementar sob diferentes níveis de adubação de cobertura nitrogenada e potássica. Revista Brasileira de Agricultura Irrigada, Fortaleza, v. 3, n. 1, p. 3 - 12. 2009.

SILVA, M. de A.; SOARES, R. A. B.; LANDELL, M. G. A.; CAMPANA, M. P. Agronomic performance of sugarcane families in response to water stress. Bragantia, Campinas. v. 67 n. 3, p. $656-661.2008$.

SINGH, P. N.; SHUKLA, S. K.; BHATNAGAR, V. K. Optimizing soil moisture regime to increase water use efficiency of sugarcane (Saccharum spp. Hybrid complex) in subtropical India. Agricultural Water Management, Amsterdam, n. 90, p. 95 - 100, 2007.

SOUSA, E. S. de; LIMA, F.W.B.; MACIEL, G. F.; SOUSA, P. de; PICANÇO, A. P. Balanço hídrico e classificação climática de Thornthwaite para a cidade de Palmas - TO. In: XVI CONGRESSO BRASILEIRO DE METEOROLOGIA, 16., 2010, Belém. Anais... Belém: Associação Brasileira de Meteorologia, 2010. 1- CD-ROM.

SOUZA, J.L.; MOURA FILHO, G.; LYRA, R.F.F. TEODORO, I.; SANTOS, E.A.; SILVA, J.L.; SILVA, P.R.T.; CARDIM, A.H.; AMORIN, E.C. Análise da precipitação pluvial e temperatura do ar na região do tabuleiro costeiro de Maceió, AL, período de 1972-2001. Revista Brasileira de Agrometeorologia, Santa Maria, v.11, n.2, p.131-141, 2004.

STUPIELLO, J. P. ART ou ATR. STAB, Piracicaba, v. 28, n. 2, p. 12, nov./dez. 2009.

TEJERA, N. A.; RODÉS, R.; ORTEGA, R. C.; LLUCH, C. Comparative analysis of physiological characterístics and yield components in sugarcane cultivars. Field Crops Research, Amsterdam, n. 102, p. 64-72. 2007.

TEODORO, I.; SOUZA, J. L.; BARBOSA, G.V.; MOURA FILHO, G.; DANTAS NETO, J.; ABREU, M. L. de. Crescimento e produtividade da cana-de-açúcar em cultivo de sequeiro nos tabuleiros costeiros de Alagoas. STAB, Piracicaba, v. 27, n. 4, p. 46 - 49, mar./ abr. 2009 
THORNTHWAITE, C. W.; MATHER, J. R. The water balance. Publication in climatology. New Jersey: Drexel Inst. Of Tecnology, 1955. 104p.

WIEDENFELD, B.; ENCISO, J. Sugarcane responses to irrigation and nitrogen in semiarid south Texas. Agronomy Jornal, Madison, v. 100, n. 3, p. 655 - 671, maio/jun. 2008. 